\title{
أحكام النقاب عند الألباني والأئمة الأربعة
}

\author{
Amri Azhari \\ Alumni Magister Hukum Islam Universitas Muhammadiyah Surakarta dan Penceramah \\ Tinggal di Jakarta
}

E-Mail: amriazharilcmh@gmail.com

\begin{abstract}
There are two different thoughts of the scholars since the last period to the present about the use of Veil. The first thought which oblige a woman Muslim to close the face [Veiled] in front of the male who is not her Mahram; because the face is a primary body part that must be covered. This thought being the opinion of Imam Ahmad bin Hambal, and a strong thought of Imam Syafi'i. The second opinion says Istihbab [Highly recommended], this being the opinion of the Imam Malik and Abu Hanifah's thought and Imam Malik, but, on the other thought of Hanafi and Maliki, since then, they oblige a veiled woman when they're worried about a slander that will occurr to them. It could happen to her if she is pretty girl, so it appears a libel damages and a malice outbreaking. As this opinion asserted by Al imam Ibn 'Abidin Alhanafi his book [Raddul Muhtar' Ala Addurul Mukhtar] said: the young girl is prohibited to open her face in the presence of a male [that is not her mahram], it does not because of the face is a body part that must be covered, nevertheless it is concerned as a defamation that occur to the tempted men though his desires are not appeared. Then, the thought about this istihbab is strongly assumed by Shaykh Muhammad al-Albani, a great scholar in the field of Hadith. In addition, he also has a considerable role in enriching the treasure in the field of Islamic law by producing a good works such as the book: (Hijab Almar-ah Almuslimah Fii Alkitaab Wa Assunnah) and a book (Arradul Mufhim 'Ala Man Khalafa Al ulamaa Wa tasyadda Wa ta'shshaba Wa alzama Almar ata antastura Wajhaha Wa kaffaiha Wa awjaba Wa lam yaqna 'Biqaulihim Innahu Sunnatun wa Mustahabbun). those two books were his Ijtihad about the use of the veil and islamic law. Mustahabbun/Sunnah (highly recommended for Muslim women and it does not up to the obligatorily required status). Based on the some Imam Madzhab's thought being compared with the opinions of Shaykh Muhammad al-Albani about the veil, as a result, the author of this scientific works has aims to explain a different thought among Mutaqaddimin and Muakhkhirin scholars about the veil. I pray to Allah, may Allah gives a great benefits, Aamiin Yaa Rabbal 'alamiin.
\end{abstract}

Keywords: law, Veil, Al Bani, Imam Madzhab.

Abstrak: Para Ulama sejak dahulu sampai sekarang berselisih paham tentang hukum Cadar dangan dua pendapat: yang pertama pendapat yang mewajibkan seorang wanita muslimah untuk menutup wajah [ Bercadar ] didepan laki-laki yg bukan Mahram; dikarenakan Muka adalah Aurat yang wajib di tutut, hal ini menjadi pendapat Imam Ahmad bin Hambal, dan pendapat yang kuat dalam madzham Imam Syafi'. Yang kedua pendapat yang mengatakan Istihbab [ Sangat di anjurkan], ini menjadi pendapat Madzhab Imam Abu Hanifah dan Imam Malik, Namun di sisi lain para ulama Hanafi dan Maliki- sejak dahulu kala meraka mewajibkan wanita bercadar ketika di khawatirkan terjadinya fitnah yang akan menimpanya; hal tercebut bisa terjadi jika seorang wanit yg cantik maka timbullah fitnah berupa kerusakan dan merebaknya kefasikan. Sebagaimana pendapat ini di tagaskan oleh Al imam Ibnu 'Abidin Alhanafi di dalam kitab beliau [ Raddul Muhtar 'Ala Addurul Mukhtar ] berkata: Wanita yg masih muda di larang membuka wajah di hadapan laki-laki [ yg bukan mahram baginya], bukan karena wajah iyu Aurat, namun khawatir fitnah yg akan menimpa laki- laki seperti terlena/ tergoda walaupun tidak bangkit syahwatnya. Lalu pendat yg mengatakan Istihbab ini di kuat oleh Syaikh Muhammad Nashiruddin al Albani, beliau adalah seorang yang mampuni dalam bidang hadits. Di samping itu beliau juga memiliki peran yang cukup besar dalam memperkaya khazanah dalam bidang hukum-hukum Islam dengan karya-karya yang bermutu semisal buku beliau: ( Jilbab Almar-ah Almuslimah Fii Alkitaab Wa Assunnah) Dan kitab (Arradul Mufhim 'Ala Man Khalafa Al ulamaa Wa tasyadda Wa ta'shshaba Wa alzama Almar-ata An Tastura Wajhaha Wa kaffaiha Wa awjaba Wa lam yaqna' Biqaulihim Innahu Sunnatun Wa Mustahabbun dua buku tersebut merupakan Ijtihad beliau tentang hukum Cadar dalam huk um Islam yaitu: Mustahabbun/ Sunnah ( Sangat di anjurkan bagi wanita muslimah dan tidak sampai ke status Wajib). Berangkat dari pendapat Para Imam-imam Madzhab dan di 
PROFETIKA, Jurnal Studi Islam, Vol. 19, No.1 Juni 2018: 51 - 66

bandingkan dengan pendapat Syaikh Muhammad Nashiruddin al Albani tentang Cadar, maka Penulis karya Ilmiah ini bertujuan untuk menjelaskan khilafiyah di antara ulama Mutaqaddimin dan Muakhkhirin tentang Cadar tersebut. Saya berdoa kepada Allah Suabhanu Wata'aala memberikan Manfa'at yang besar, Amiin Ya Rabbal 'Alamiin .

Kata kunci: Hukum Cadar, Al Bani, Imam madzhab.

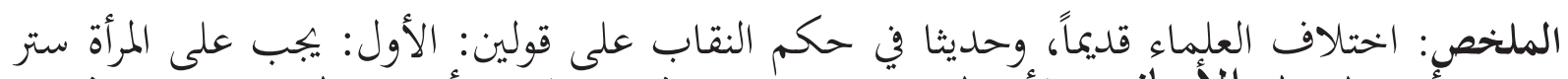

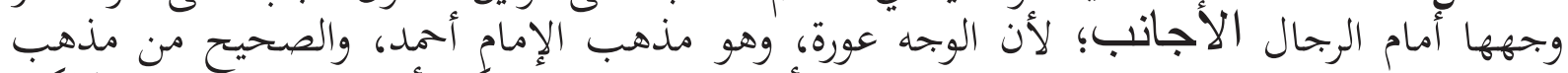

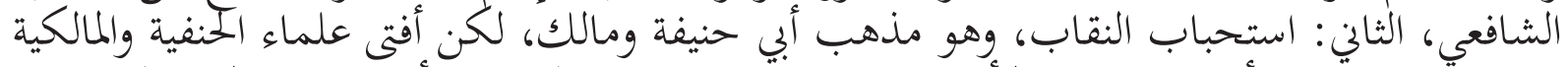

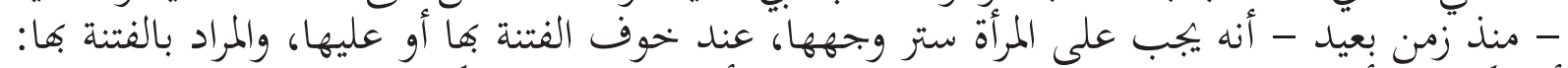

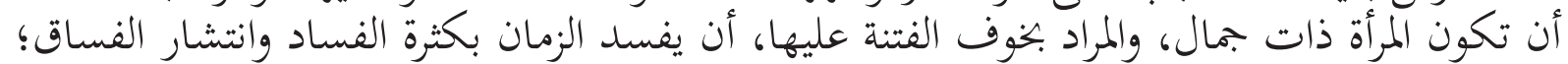

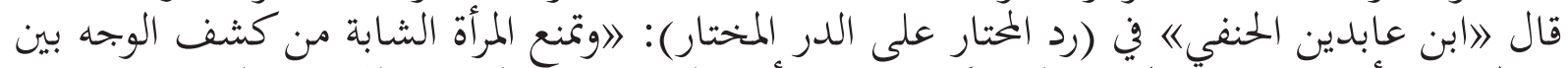

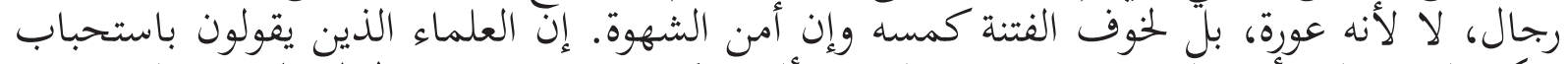

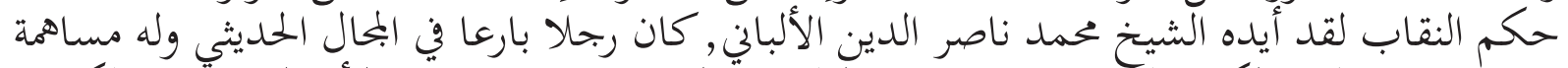

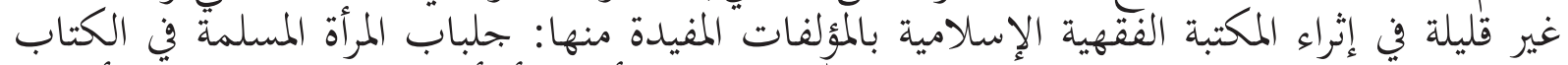

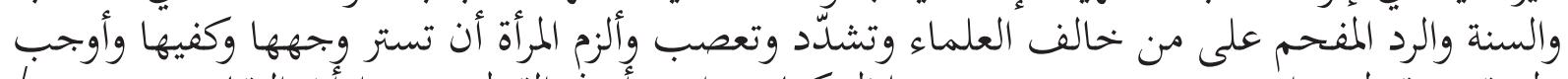

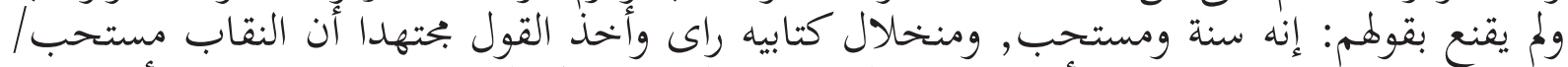

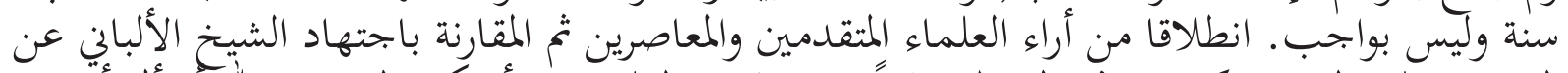

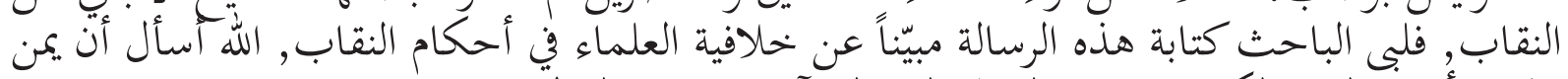

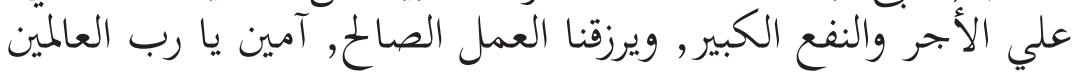
الكلمات الرئيسة: الحكم, النقاب النحر, الألباني, الأئمة الأربعة.

\section{المقدمة}

إن الشيخ محمد ناصر الدين الألباني- رحمه الله

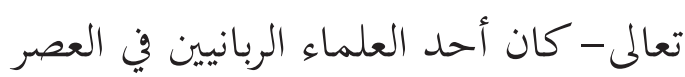

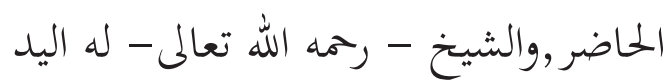

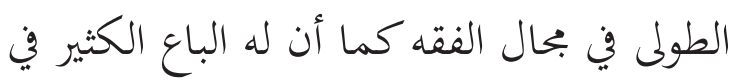

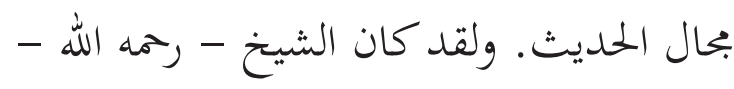

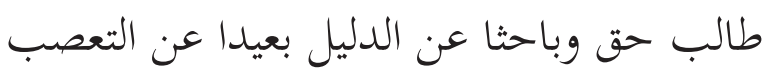

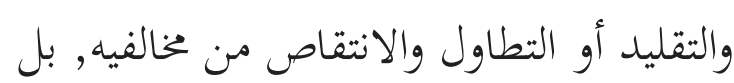
كان أشد الناس تحذيرا من الرأي وأهله, و و والثطاص

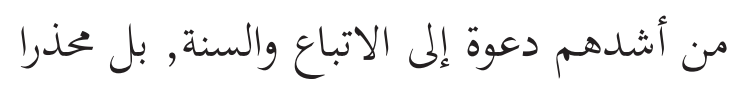

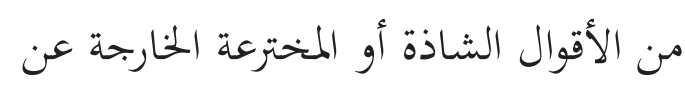
اجتهادات أهل العلم من السلف الصالح.

ولا شك في ذلك, فهو امتداد لمدرسة علمية تنبذ التقليد وتقدم الدليل على دآراء الرجال,

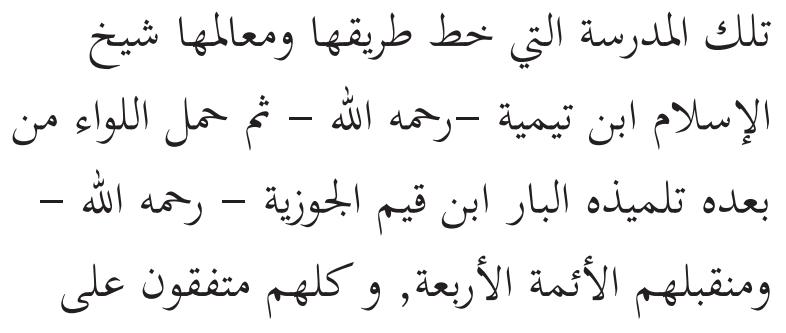

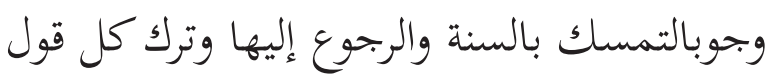
يخالفها مهما كان القائل عظيما. لذلك كان الشيخ يختار آراهه ويرجحها وإن خالف أقوالهم, فكانت ترجيحاته توافق أحد

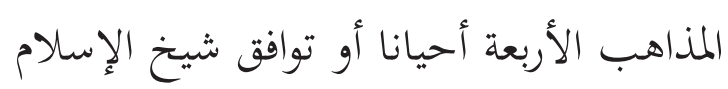

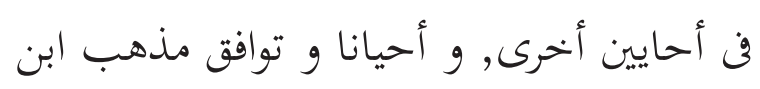

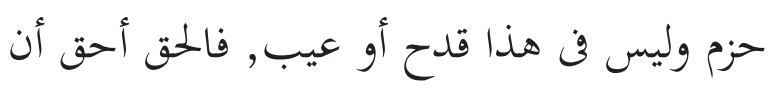

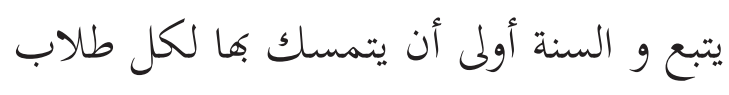
العلم فضلا عن علمائهم. 
أحكام النقاب عند الألباني والأئمة الأربعة (Amri Azhari)

و كان من البديهي ألا يتقيد الشيخ بمذهب

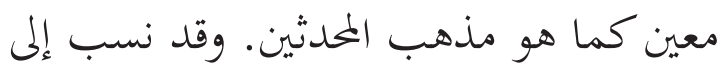

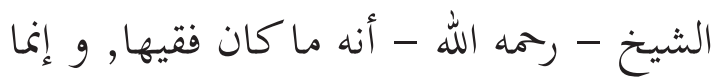
كان محدثا, فلا يؤخذ منه المسائل الفقهية,

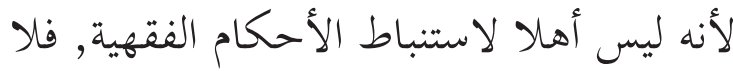

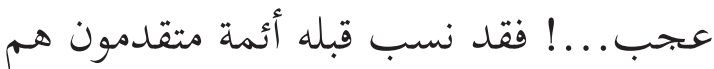

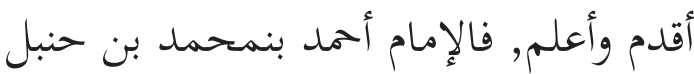

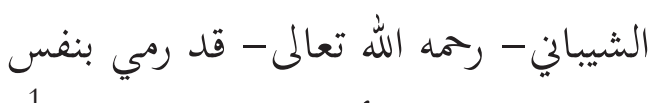

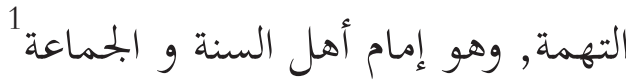

هذا هو الشيخ الألباني في سعة علمه علم الحديث والفقه, ومع ذلك لقد خحالف الألباني

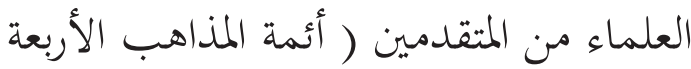

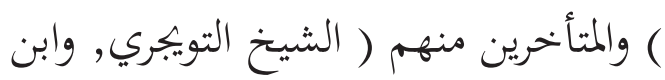

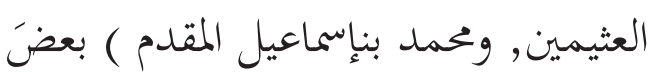
المسائل التي اجتهد فيها الشيخ وهي: مسالة

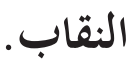

مما سبق ذكره تبين أهمية البحث العلمي في

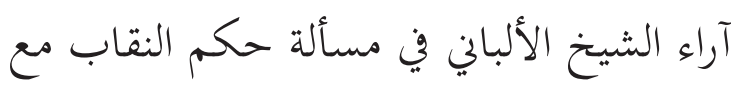
المقارنة بأقوال الأئمة الأربعة وعلماء المعاصرين. وبناءً على ما سلف عرضه من اختلاف الحكم

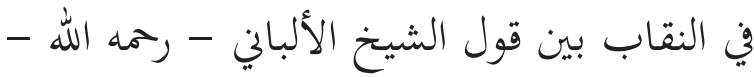
الذي قال: بجواز كشف وجه المرأة المسلمة أمام الرجال الأجانب , وبين معاصريه من العلماء

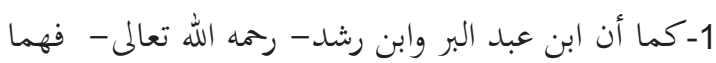

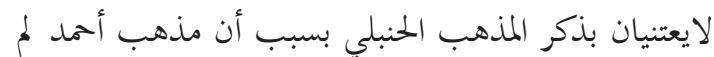

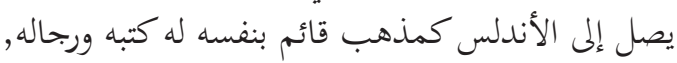

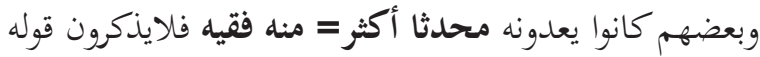

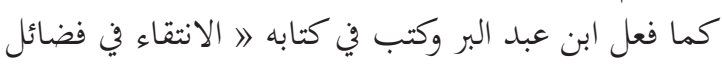

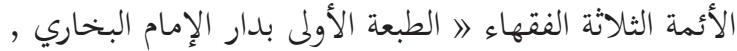
الدوحة - قطر - , والله أعلم.
الذين يذهبون بوجوب ستر وجه المرأة المسلمة أمام الرجال الأجانب ذلك مستدلين بأن وجهه

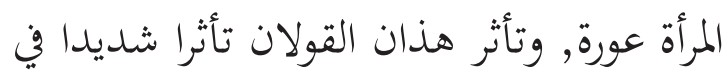
بحتمع بلدنا أندونسيا, وعليه فإن السؤال يطرح

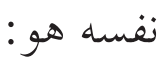

1- ما حكم النقاب عند الألباني والأئمة الأربعة, ما هي أدلتهم, وكيفية استدلالهم

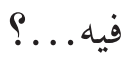

2- و هل رأي الألباني موافق لما ذهب إليه العلماء أو هو رأي شاذ.. ؟ الإي مواف مأ

3- ما هو القول الراجح بين الأئمة الأربعة والشيخ الألباني في النقاب ؟ إنول بين

4- ما هي الشبهات التي شوهتها الجهلة المنحرفون الذين يدعون شعار تحرير المرأة المسلمة من الضيق والخمول والتأخر في الحياة

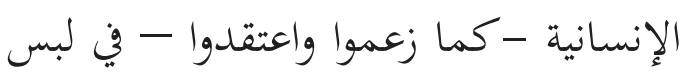
الحجاب لا سيما النقاب...؟

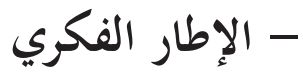
ومن المهم التنبيه إلى الإطار الفكري

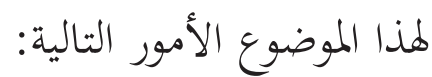

1- معرفة أن الشرع ينقسم إلى ثلاثة أقسام:

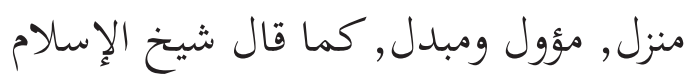
ابن تيمية2

2- أحمد بن عبد الحليم بن عبد السلام ابن عبد الله بن أبي تئي 
PROFETIKA, Jurnal Studi Islam, Vol. 19, No.1 Juni 2018: 51 - 66

الأول: الشرع المنزل وهو ما جاء به الرسول

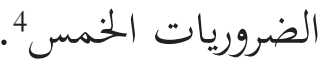

وهذا يجب اتباعه ومن خالفه وجبت عقوبته.

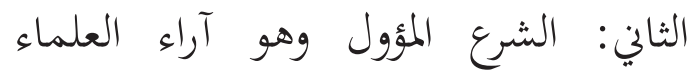

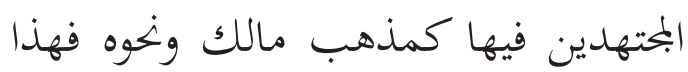

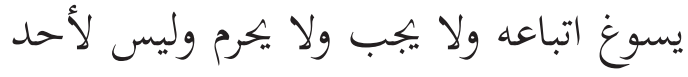

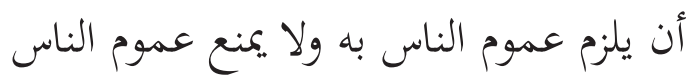

الثالث: الشرع المبدل وهو الكذب على الله ورسوله أو على الناس بشهادات الزور ونهوها

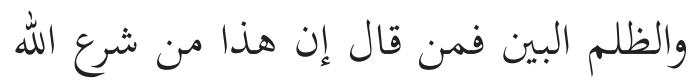
فقد كفر بلا نزاع كمن قال إن الدم والميتة حلال ولو قال هذا مذهبي ونحو ذلكُ3.

2- تطبيق المقاصد الشريعةفي اللباس تحقيقا

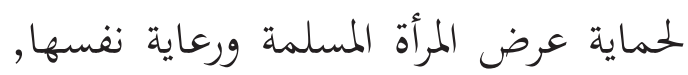

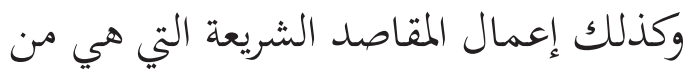

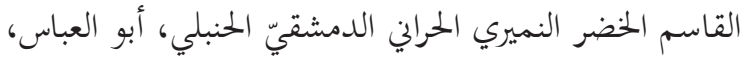

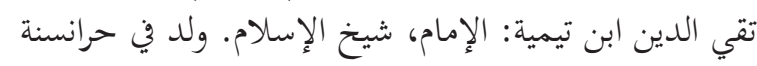

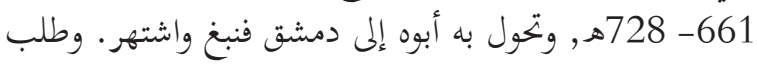

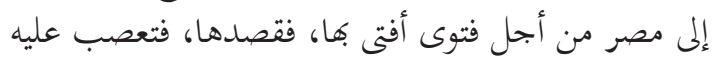

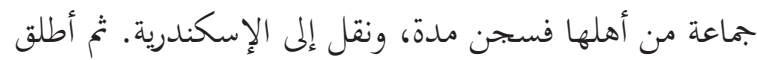

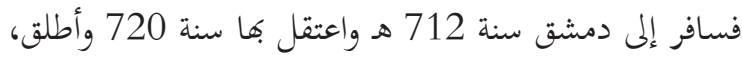

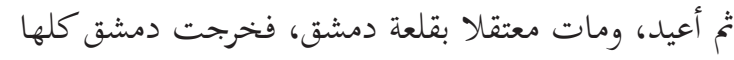

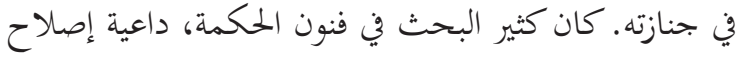

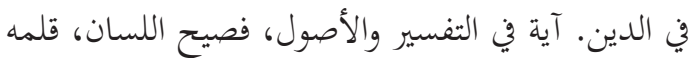

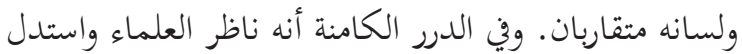

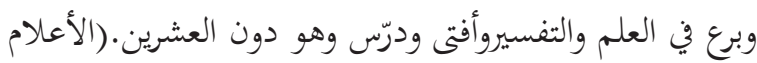

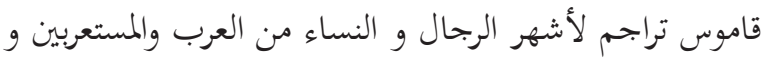

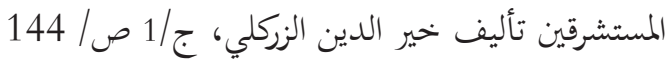

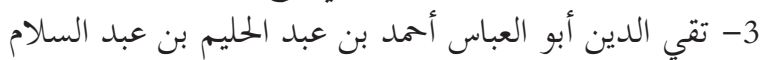

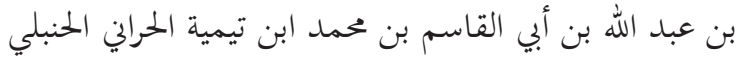

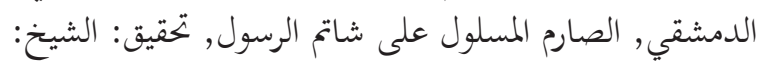

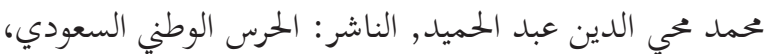
المملكة العربية السعودية, ص249 الحمبند

تتكون منهجية البحث في هذا البحث م نوع البحث ومنهجه ومصادر المعلومات وطريقة كتابة البحث وبياها فيما يلي : قمتفيدراستي هذه ببحثموهوجمعالبياناوالمواد التى أخذذت من الكتب والبحوث العلمية المتعلقة بعنوان الماني لبحث, وسلك الباحث مناهج البحث ما يلى :

1- الطريقة المباشرة وهي: جمع المعلومات الأساسية والثانوية وتحليلها وما كتبه الشيخ الألباني بخاصة كتابيه : - - جلباب المرأة المسلمة في الكتاب والسنة, الناشر: دار السالام, تاريخ

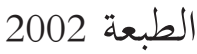
- الرد المفحم على من خالف العلماء وتشدّد وتعصب وألزم المرأة أن تستر

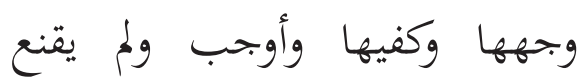
بقولم: إنه سنة ومستحب, الطبعة الأولى اب § اهـ, المكتبة الإسلامية,

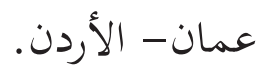
ثم ألحقتها بالمقارنة النقدية على الأئمة الأربعة وأدلتهم وأقوال المشائخ المعاصرين.

2- الطريقة غير المباشرة وهي أخذ المواد 4- بحموع الفتاوى، الجزء 3، صفحة 268. 
أحكام النقاب عند الألباني والأئمة الأربعة (Amri Azhari)

وجوهرة الفكرة من بعض العلماء مع بعض

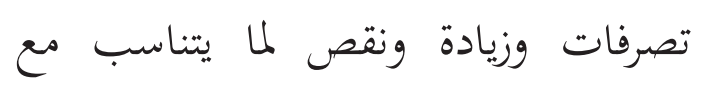

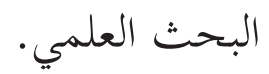

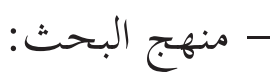

رتفيهعلنالمنهج الاستقرائي حيثس الث تتبعت أقوال الألباني التي تتعلق

بالحجاب/النقاب ثم ألحقتها بالمقارنة

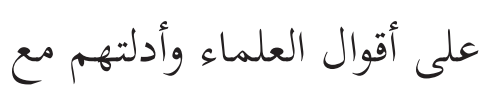

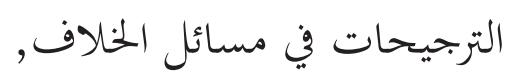

فجمع الباحث الكتب والبحوث المتعلقة بها ومراجعتها لذلك الك الك وتتبع الكتب من العلماء القدماء والمعاصرين والدراسة الأكادمية والرسائل والمقالات والاعتماد وند الكتابة على المصادر الأصلية في مسألة بحسبها. وكتبت هذا البحث مع مراعاة هذه الأمور:

1- قسمت هذا البحث إلى أبواب وفصول ومباحث همت

2- عزوت الآيات إلى موضعها

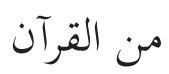

3-خرجت الآحاديث والأثار إلى مصادرها بذكر مخرجيها حاولت أنأبين صحة الحديث من أقوال المققين إذا كان في غير الصحيحينحسب الإمكان
واعتمدت على تصحيحات الألباني وغيره إن وجدات.

4- قمت بترجمة الأعلام على حسب طاقتي

5- حرصت على جمع المعلومة من المصادر الأصلية مباشرة

6- عند الإحالة إلى المصدر،

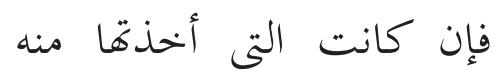
كاملة فإين أذكرها مباشرة, وإن كنت أخذت مضموها أو استأنس فإني أذكره مصدرا بلفظ "انظر 7- وضعت فهريس كما يلي : - فهرس المصادر والمراجع - فهرس الموضوعات التعريف بمفردات موضوع البحث

يشتمل على التمهيد وخمسة فصول

التمهيد:فيه مبحثان اثنان المبحث الأول:الأحكام لغة واصطالاحما . الأحكام لغة: جمع الحكىم.

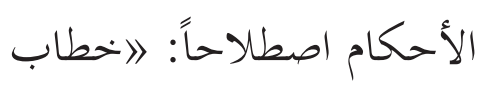
الله المتعلق بفعل المكلف اصلف اصلف 
PROFETIKA, Jurnal Studi Islam, Vol. 19, No.1 Juni 2018: 51 - 66

بالاقتضاء، أو التخيير"

المبحث الثاني:تعريف النقاب

والألفاظ ذات الصلة به

وتعريفها.

من معاني النقاب في اللغة:

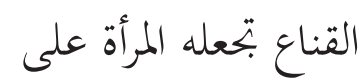

مارن أنفها تستر به وجهرها

والجمع نقب, ولا يخرج المعنى

الاصطلاحي عن المعنى اللغوي

الألفاظ ذات الصلةوتعريفها:

1- الخمار 2- الحجاب3-3

البرقع4- اللثام 5- البماركا

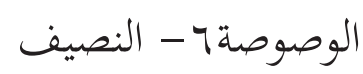

أما تعريفات تلك الألفاظ فقد

بيتُها في الباب الثاني من هذه

$$
\text { الرسالة. - الر. }
$$

الفصل الأول: ترجمة موجزة

$$
\text { عن الشيخ الألباني }
$$

ترجم الباحث ترجمةموجزة

عن الشيخ الألباني كما يلي:

اسمه ومولده ونشأته, بداية طلبه للعلم, توجهه إلى علم الحديث

$$
\text { واهتمامه بـه }
$$

شيوخه, تلاميذه, دروسه

وبحالسه العلمية, كتبه ومؤلفاته,

$$
\text { ثناء العلماء عليه, ثمخ }
$$

وفاته - رحمه الله تعالى -

الفصل الثاني: ترجمة موجرة عن الإمام أبي حنيفة ترجم الباحث ترجمة

موجزة عن إمام أبي حنيفة كما يلي:

اسممه ومولده ونشأته, بداية طلبه للعلم, توجههه إلى علم الحديث واهتمامه بها ,

شيوخه, تلاميذه, كتبه ومؤلفاته, رحم-ثناء العلماء عليه, ثتم وفاته الله تعالى - رهلى الفصل الثالث: ترجمة موجزة عن الإمام مالك ترجم الباحث ترجمة موجزة عن الإمام مالككما يلي: اسممه ومولده ونشأته, بداية طلبه للعلم, توجهه إلى علم الحديث واهتمامه به, شيوخه, تالاميذه, كتبه ومؤلفاته, ثناء العلماء عليه, ثتم وفاته -

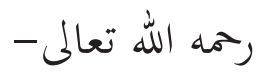
الفصل الرابع: ترجمة موجزة عن الإمام الثافعي ترجم الباحث ترجمة موجزة عن الإمام الشافعيكما يلي: اسمه ومولده ونشأته, بداية طلبه 
أحكام النقاب عند الألباني والأئمة الأربعة (Amri Azhari)

للعلم, توجهه إلى علم الحديث

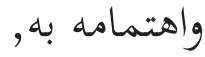

رحلاته في الطلب, شيوخه, تلاميذه, كتبه ومؤلفاته, ثناء العلماء عليه, ثم وفاته - رحمه

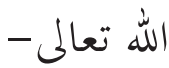

الفصل السادس: ترجمة موجزة عن الإمام أحمد بن

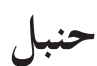

ترجم الباحث ترجمة موجزة

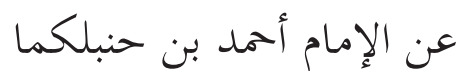
يلي:

اسمه ومولده ونشأته, بداية طلبه للعلم, توجهه إلى علم الحديث واهتمامه به ,

رحلاته في الطلب, شيوخه,

تلاميذه, كتبه ومؤلفاته, ثناء

العلماء عليه, ثم وفاته - رحمه

الله تعالى الهداء عليه

مفهوم الخحلاف, أسبابه, وبعض صوره الفصل الأول: مفهوم الخهاوف الون

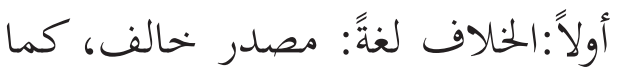
أن الاختلاف مصدر اختلف.

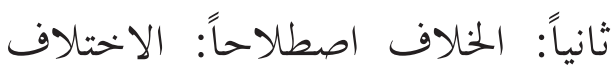
والمخالفة: أن يأخذ كل واحد طريقاً غيرطريق الآخر في حاله أوقوله. أما في الاصطلاح الفقهي والعلمي فالذي يستقرى استخدام علماء
وفقهاء المسلمين لهذين اللفظين، يجد أن عامتهم لا يفرقون بينهما عند الاستخدام, وإن كانوا يفرقون بين

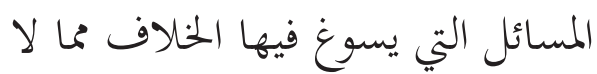
يسوغ فيها، مع اختلاف تعبيراتم عن هذه التفرقة.

الفصلالثاني: أسباب الخحلاف بين العلماء لقد أحسن شيخ الإسلام ابن تيمية -

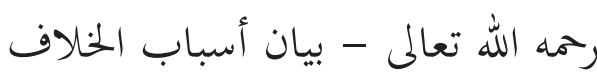
بين العلماء قائلاً: الأسباب التي دعت العلماء إلى مخالفة بعض النصوص, و.ميع الأعذار ثناثة أصناف 5

أحدها : عدم اعتقاده أن النبي صلى

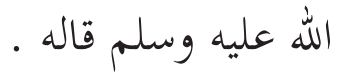

والثاني : عدم اعتقاده إرادة تلك المسألة

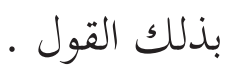

5- ابن تيمية الشيخ الإمام العلامة الحافظ الناقد الفقيه البحتهد

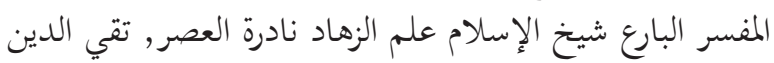

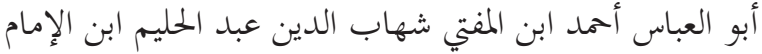

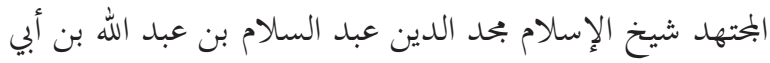

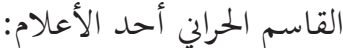

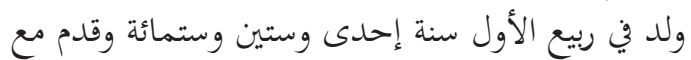

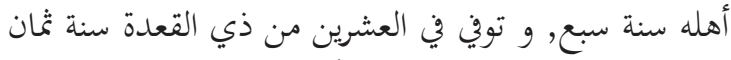

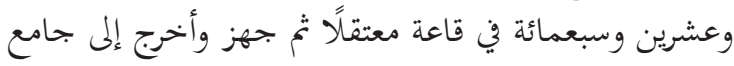

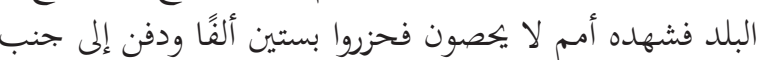

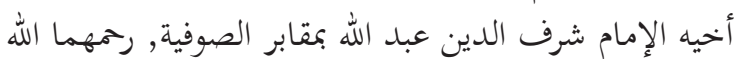

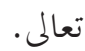
ينظر: تذكرة الحفاظ, تأليف: محمد بن أحمد بن عثمان

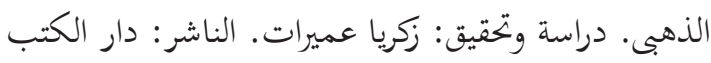

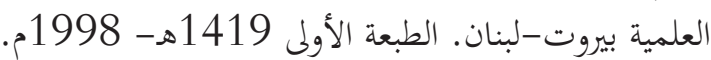
ج/4/ص/ 129 
والثالث : اعتقاده أن ذلك الحكم

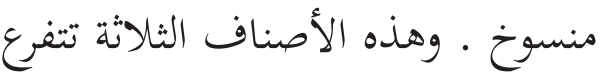

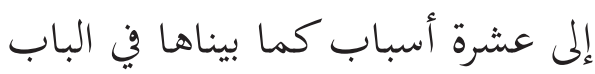
الثالث من هذه الرسالة.

الفصل الثالث: أسباب وقوع خلاف بعض علماء المعاصرين تجاه آراء

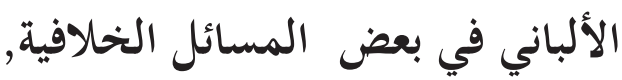
ترجع إلى شبهاتثارت حولها بيّن الباحث عن سبب الخلاف الفقهي بين الألباني وأقرانه - رحمهم الله بله جميعا-, ويتكن من سبعة مباحث: المبحث الأول: نفي الفقه عنه,

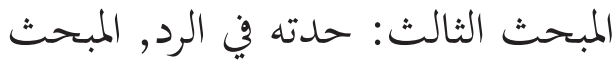
الرابع: نسبته إلى المرجئة !, المبحث الخامس: حجية حديث الآحاد في العقائد والأحكام, المبحث السادسة حلديث الاديد اتمموه باللامذهبية !, المبحثالسابع:

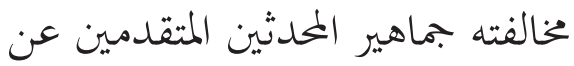
تطبيق القواعد الحديثية في التصحيح والتضعيف.

الفصل الرابع: هل الخلاف الذي وقع بين الألباني وبين جماهير العلماء خلاف هل الحاف الدي وفع

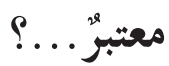

لا بد أن نعرف مفهوم الشاذ ثم نطبقه في واقع الحال.

6-رفع الملام عن الأئمة الأعلام, تأليف: شيخ الإسلام تقي

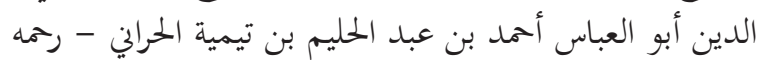

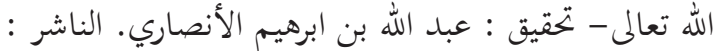
المكتبة العصرية، بيروت، لبنان.
الشاذ في اللغة: هو المنفرد أو الخارج عن

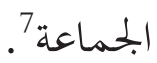
أما في مفهوم الفقهاء فقد قال ابن

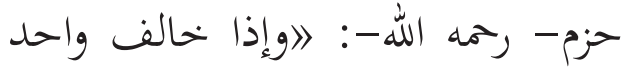
منالعلماء جماعة فلا حجة في الكثرة لأن الله تعالى يقول :" وقليل ما هم" الشاذ اصطلاحا: هو التفرد بقول مخالف للحق بلا حجة معتبرة. قد رأى الألباني أن الشذوذ بعترة المذموم هو

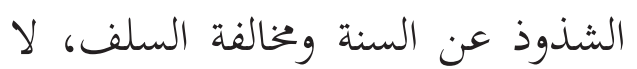
مخالفة الجمهور في المسائل الفقهية، حيث قال- رحمه الله-: اليعني الشذوذ

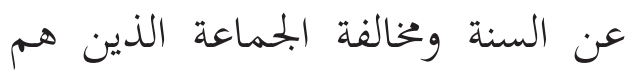
السلف كما علمتَ.

الفصل الخامس:نماذجالخلاف بين العلماءالمعاصرين وفيه ثلاثةمباحث:

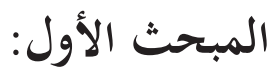

الخلاف بين الألباني و التويجري-

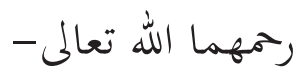

ذلك الخلاف ما وقع بين الشيخين الجليلين - رمهما الله تعالى-الألباني والتويجري . لقد وقع الخلاف بينهما في " مسألة النقاب 》ا, ذلك بعد أن ألف الشيخ 7- للدكتور إبراهيم أنيس وغيره, المعتم الوسيط ج 1 ص صل

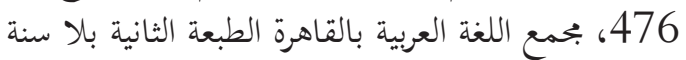
8- سورة ص: الآية 276

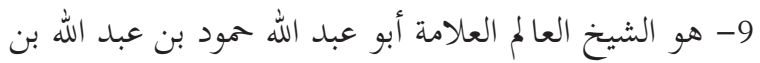

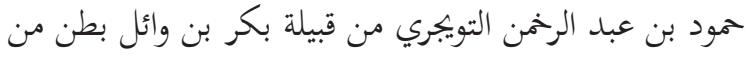

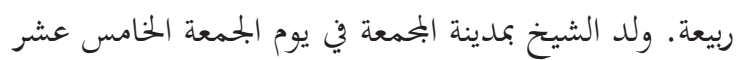


أحكام النقاب عند الألباني والأئمة الأربعة (Amri Azhari)

الألباني كتابه المسمى 》 (حجاب المرأة المسلمة في الكتاب والسنة).

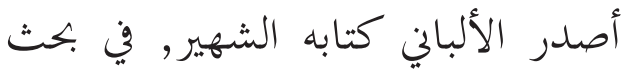

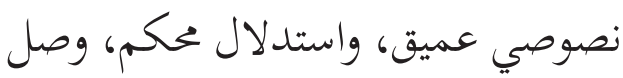
الألبالي إلى أن وجه المرأة ليس بعورة، وأن ستره ليس بواجب إلا على زوجات النبي

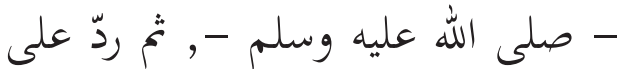
الألباني الشيخ العلامة حمود بن عبدالله التويجري- رحمه الله تعالى- في كتابه النفيس(الصارم المشهور على أهل التبرج

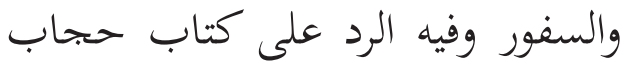

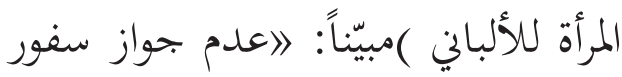

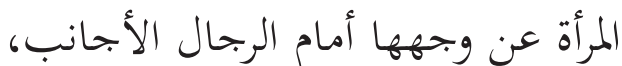
خلافًا لقول الشيخ ناصر الدين الألباني بجواز كشف المرأة وجهها وكفيها، ويبين أضرار ومساوئ هذا الأمر،

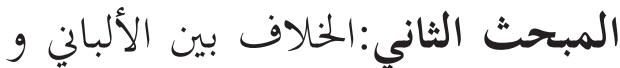

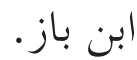

ذلك الخلاف ما وقع بين الشيخين الجليلين - رمهما الله تعالى-الألباني والشيخ عبد العزيز بن باز 10.

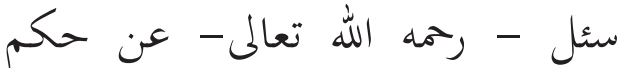

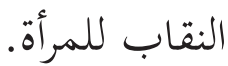

من شهر ذي = الحجة سنة المبكاءهر, وقد وافاه أجله في آخر

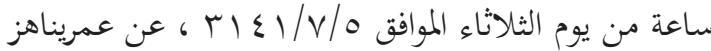

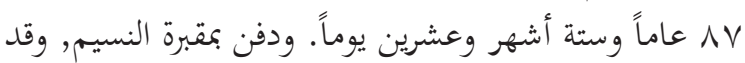
أم المصلين سماحة الشيخ بن باز - رممه الله تعالى - . library/0/39448/\#ixzz55k6qQ46R

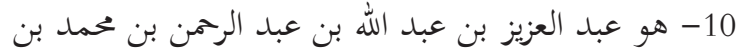
عبد الله آل باز، وآل باز أسرة عريقة في العلم والتجارة والزراعة ين العيد
فأجاب الشيخ ابن باز : المرأة عورة، والنقاب في حقها واجب، وهو ستر الوجه وستر جميع بدها عن الأجنبي

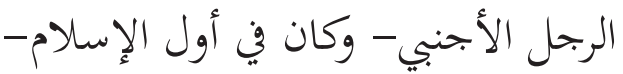
لها أن تكشف وجهها ويديها عند الرجال وتخالطهم ثم نسخ الله ذلك وأنزل :الله آية الحجاب وهي قوله سبحانه:

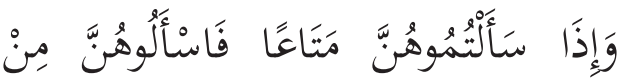
وَرَاءٍ حِجَابِ

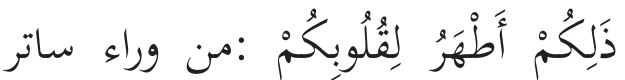

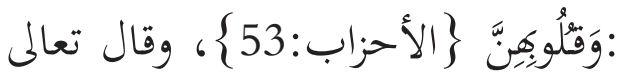

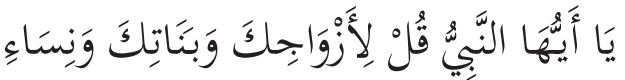

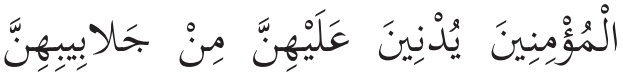

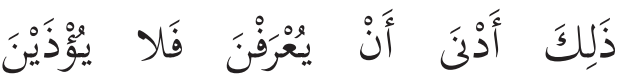
\}الأحزاب:59\{، يعرفن بالجلباب الذي يغطي وجه8ها وبدها. ثم ردّ الشيخ الألباني على هذا وحثان الفتوى بكل احترام وأدب كما بيّنه هذا الرد

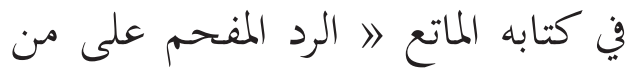
خالف العلماء وتشدّد وتعصب وألزم المرأة أن تستر وجهها وكفيها وأوجب ولم وتمبك

معروفة بالفضل والأخلاق أصلهم من المدينة النبوية، ولد في

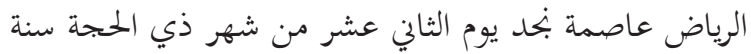

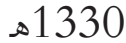

كان سماحة الشيخ عبد العزيز - رحمه الله - مبصرا في أول

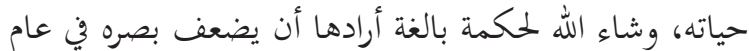

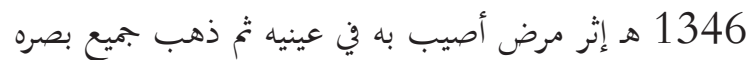

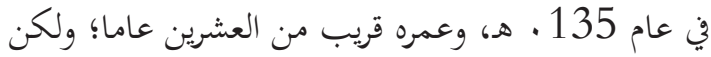

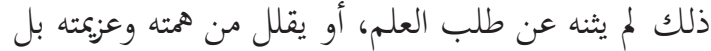

$$
\text { استمر في طلب العلم ملازما. }
$$

توفي الشيخ العلامة ابن باز عام فلازئ 1420هـ http://www.alukah.net/library/0/39448/\#ixzz- 
PROFETIKA, Jurnal Studi Islam, Vol. 19, No.1 Juni 2018: 51 - 66

يقنع بقولم: إنه سنة ومستحب111.

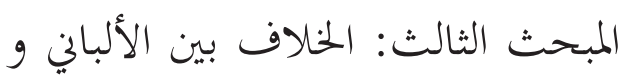

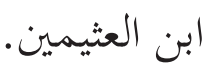

ذلك الخلاف ما وقع بين الشيخين

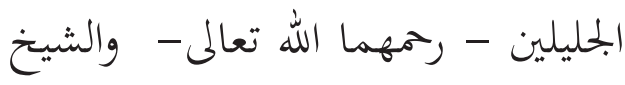
محمد بن صالح العثيمين عن حكم تغطية الوجه والكفين.

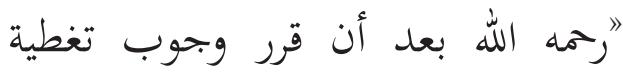

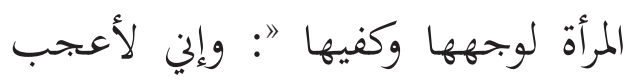
من قوم يقولون : إنه يجب على على المرأة أن تستر قدمها ، ويجوز

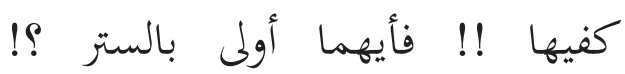

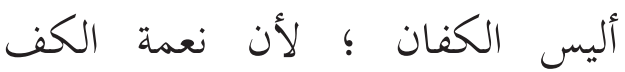
وحسن أصابع المرأة وأناملها في اليدين لاندة اليدان أشد جاذبية من ذلك في الرجليع المراة واطليا في اليدين فذهب الشيخ الألباني - رحمه الله- كما قال في كتابه ( جلباب المرأة المسلمة المباني ) بجواز كشف الوجه والكيفين, فيورد بعض الأحاديث الدالة على كشفهما. 13 11- الطبعة الأولى 1421هـ. المكتبة الإسلامية. عمان-

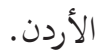

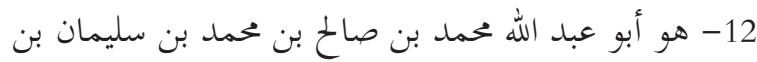
عبد الرحمن العثيمين الوهبي التميمي.

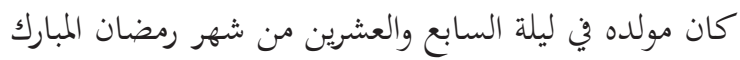

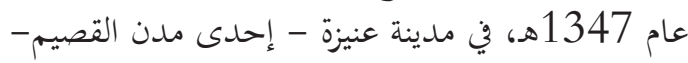
بالمملكة العربية السعودية. الحرام والمسجد النبوي في مواسم الحجج وشهر رمضان والعطل الصيفية. كان عضواً في هيئة كبار العلماء بالمملكة العبية السعودية منذ عام 1407هـ حتى وفاته -رحمه الله

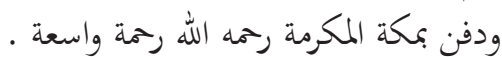
https://ar.wikipedia.org/wiki 13- الشيخ الألباني: جلباب المرأة المسلمة في الكتاب والسنة,
أحكام النقاب عند الألباني والأئمةالأربعة

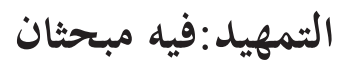

$$
\begin{aligned}
& \text { المبحث الأول:الفرق بين الجلباب } \\
& \text { والحجاب: }
\end{aligned}
$$

- الجلباب: جمعه جلابيب, فالجلباب

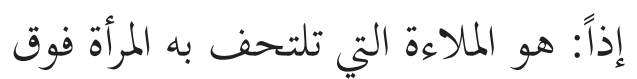
ثيابها على أصح الأقوال, وهو يستعمل إلمال في الغالب إذا خرجت من دارها ${ }^{14}$ - الحجاب:يعرف الحجاب باللغة على إلى دابل أنه الشيء الذي يحول بين شيء وآخر ويمنع ظهوره، ويعرف الحجاب بالإسلام على أنه عبارة عن رداء ترتديه المرأة المسلمة بغرض الستر وحجب جسدها عهديا وشعرها عن الظهور للرجال المخرمين عليها. أمّا الحجاب في الشّرع فله معنيان :

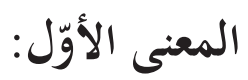
هو ما تقدّم ؛ أي بمعنى الجلباب الذي

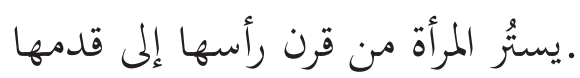
المعنى الثّاني: - مئي هو ما يحجب شخص اني" المرأة من جدار

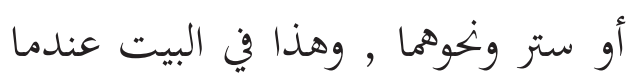
تكون غير متجلببة ولا مختمرة ؛ فلا تبرز على حالها.

14- انظر: الألبانى محمد ناصر الدين, جلباب المرأة المسلمة في

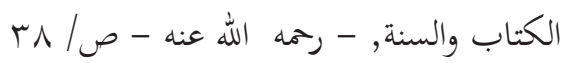


أحكام النقاب عند الألباني والأئمة الأربعة (Amri Azhari)

الفصل الأول: أدلة الألباني من القرآن

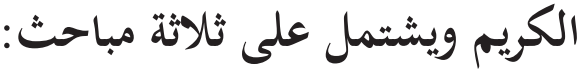

المبحث الأول: الآيات القرآنية التي تتعلق مباحت

بالحجاب منها:

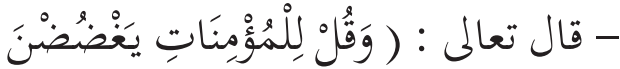

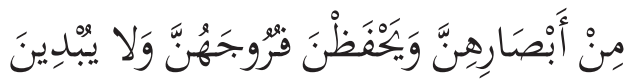

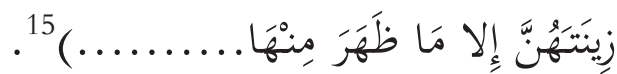

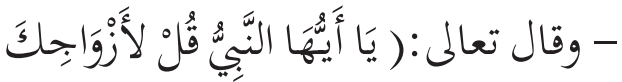

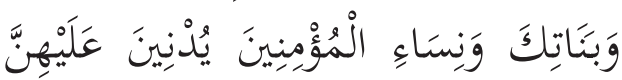

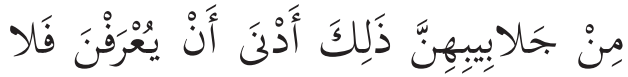

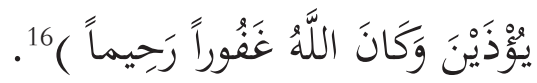

المبحث الثاني: تفسير تلك الآيات

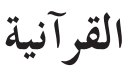

قال الحافظ ابن كثير: " لا لا يظهرن

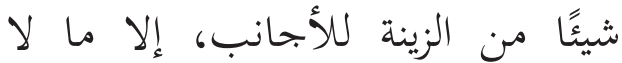

يمكن إخفاؤه، قال ابن مسعود: كالرداء

والثياب؛ يعني على ما كان يتعاطاه نساء

العرب من المقنعة المني

المبحث الثاني: تفسير تلك الآيات

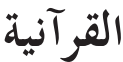

قال الحافظ ابن كثير: 》 لا يظهرن

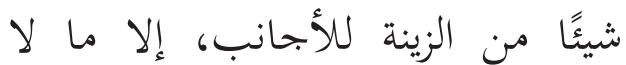

يمكن إخفاؤه، قال ابن مسعود: كالرداء

والثياب؛ يعني على ما كان يتعاطاه نساء

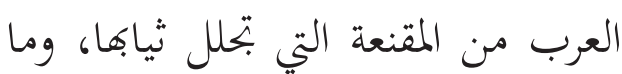

يبدو من أسافل الثياب، فلا حرح عليهيا

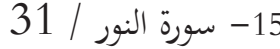

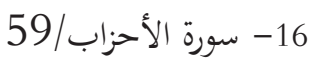

$$
\text { فيه؛ لأن هذا لا يمكن إخفاؤهب17. }
$$

المبحث الثالث: أدلثه من السنة النبوية

ويشتمل على ثلاثة مطالب:

المطلب الأول: منالآحاديث النبوية التي ملئ

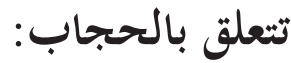

1- عن ابن عباس "عن الفضل بن

عباس": أن امرأة من خثنهم استفتت إعن العن

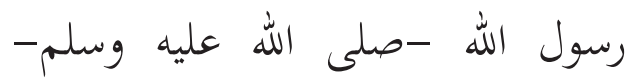

في حجة الوداع [يوم النحر] والفضل

بن عباس رديف رسول الله -صلى اللى

الله عليه وسلم-[وكان الفضل رجلاً

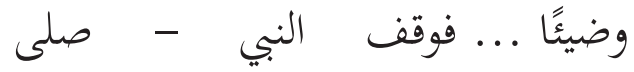

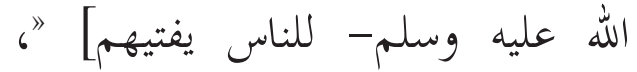

الحديثوفيه:"فأخذ الفضل بن عبل عباس

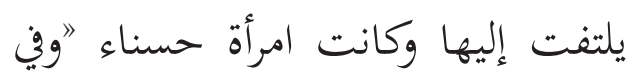

رواية: وضيئة" ”وفي رواية: فطفق الفضل

ينظر إليها وأعجبه حسنها" [وتنظر

إليه] فأخذ رسول الله -صلى الله عليه

وسلم- بذقن الفضل فحول وجههه من

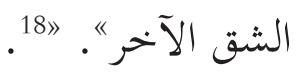

المطلبالثاني: خحلاصة تلك الآنر لآحاديث

$$
\text { النبوية والآثار . }
$$

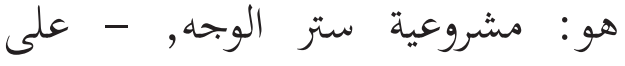

الاستحباب لا الواجب- هذا ما ذهب لوتب لونب

17- تفسير الإمام أبي الفداء إبماعيل ابن كثير ج3 ص/

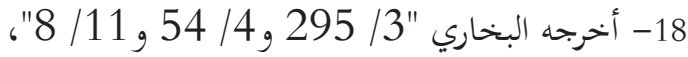

ومسلم "18/ 101"، البوالبيهقي، والزيادة الأولى بين القوسين

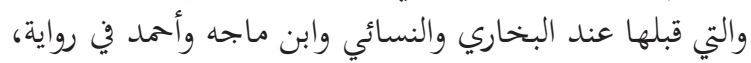

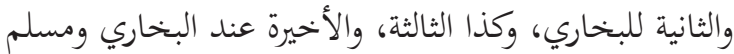

في رواية، وهي في "صحيح ابن خزيكة" "4/ 342 ". 


$$
\text { إليه الشيخ الألباني. }
$$

الفصل الثاني: أحكام النقاب عند الأئمة

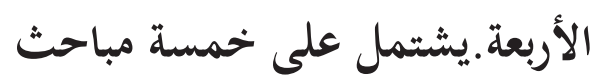

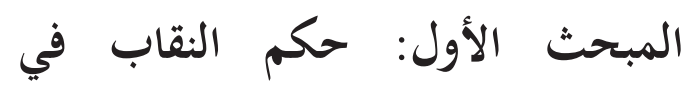
المذهب الحنفي من أقوال الأئمة الحنفية في النقاب الميف

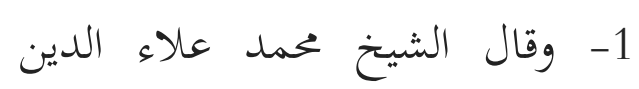
الإمام: " وجميع بدن الحرة عورة إلا وكيخ وجهها وكفيها ، وقدميها في رواية ، وكذا صوتما، وليس بعورة على الأشبه.

\section{المبحث الثاني: حكم النقاب في المذهب المالكي} من أقوال الأئمة المالكية في النقاب

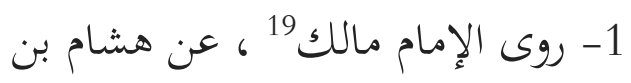

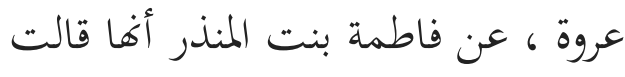

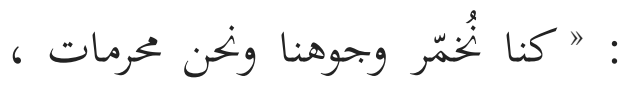

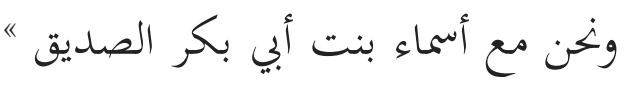

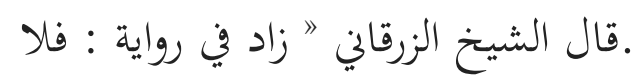

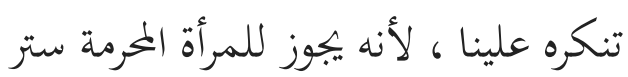

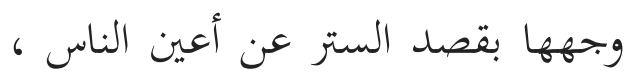

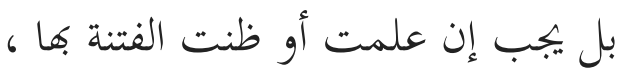

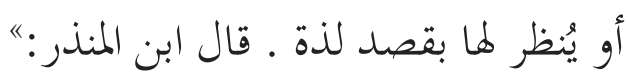

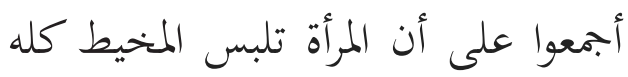

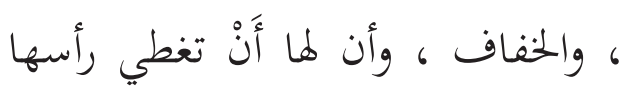

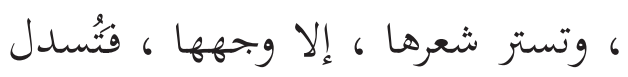

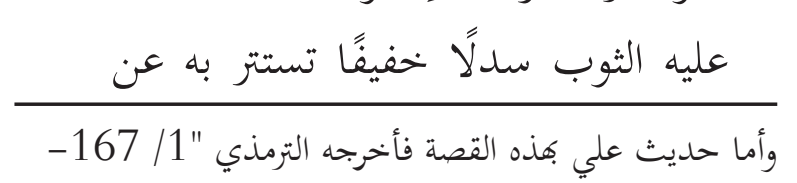

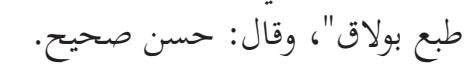
19-بشرح الزرقاني الموطأ ـ 2 / 234 بحت
نظر الرجال ، ولا تُخْمِر ، إلا ما روي

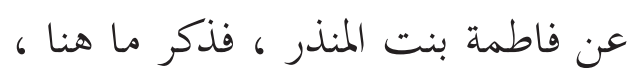
ثم قال : ويحتمل أن يكون ذلك التخمير

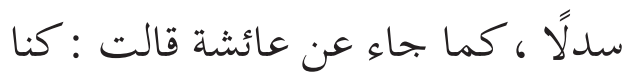

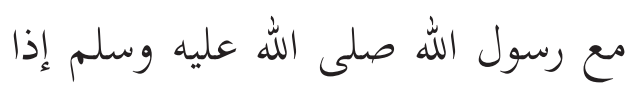

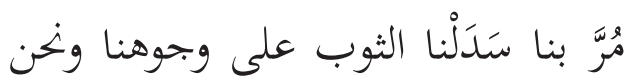

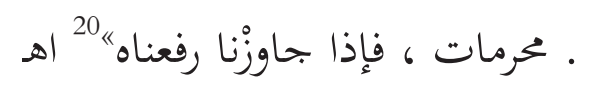

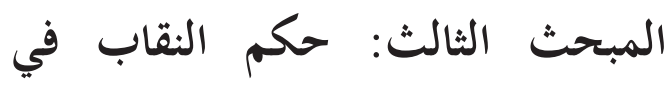
المذهب الثافعي من أقوال الأئمة الشافعية في النقاب:

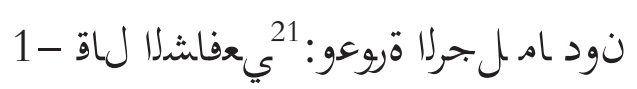

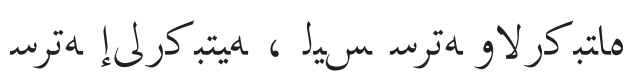

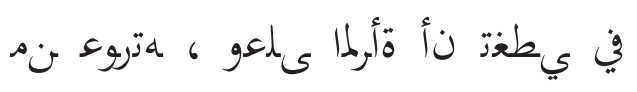

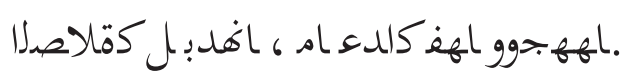

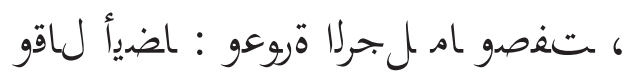

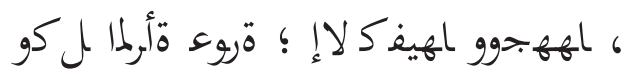

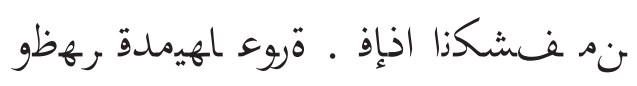

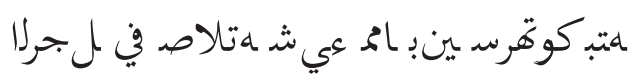

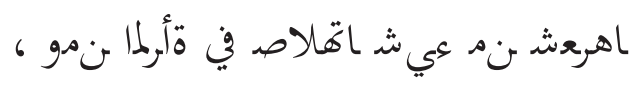

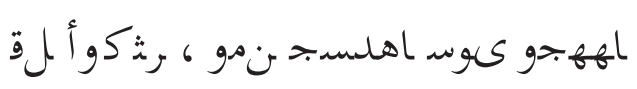
الويفكو

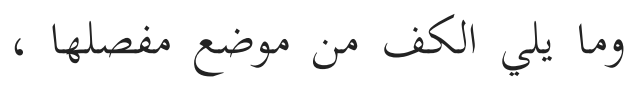
ولا يعدوه ، علما أم لم يعلما - أعادا

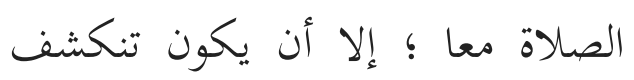

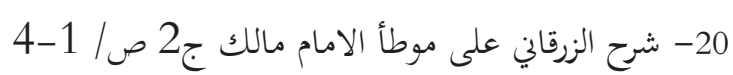

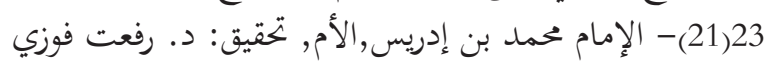

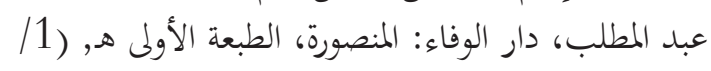
(109

22- الشافعي, الإمام محمد بن إدريس, الأم, تحقيق: د. رفعت فوزي عبد المطلب، دارالوفاء:المنصورة، الطبعة الأولى دئ دئ 
أحكام النقاب عند الألباني والأئمة الأربعة (Amri Azhari)

المبحث الرابع: حكم النقاب في

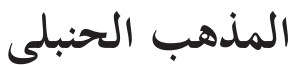

من أقوال الأئمة الحنابلة في النقاب:

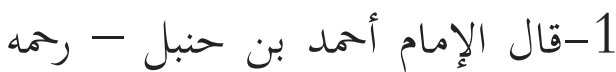

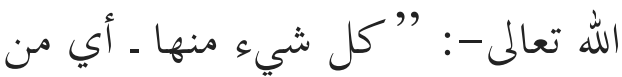
المرأة الحرة ـ عورة حتى الظفر “" أهـ 23

المبحث الخامس: تحليلات أقوال أئمة

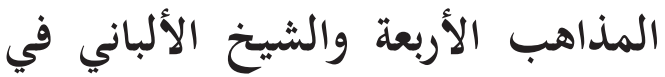

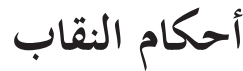

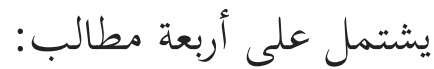
المطلب الأول: الخلاففي مسألة النقاب ابعل مطاب

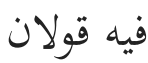
المطلب الثاني: أدلة القائلين بجواز كشف فرلف

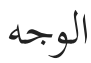

المطلب الثالث: أدلة القائلين بوجوب الته

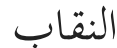
المطلب الرابع: تنبيهات مهمة

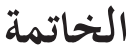

1- وجوب ستر المرأة جميع بدها ، بما في ذلك وجهها وكفيها عن الرجال الأجانب عنها ـ وقد رأى بعض أهل العلم أن الوجه والكفين عورة لا يجوز إظهارهما لغير النساء المسلمات والمحارم ، استنادًا

1422هـ, (109/1)

25(23)-جمال الدين أبو الفرج عبد الرممن بن علي بن

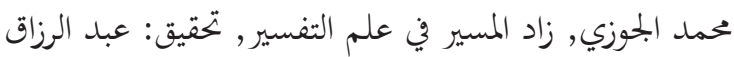

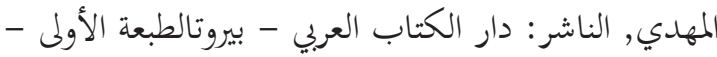

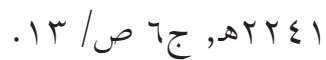

“، قروعإلى الحديث الصحيح: "المرأة

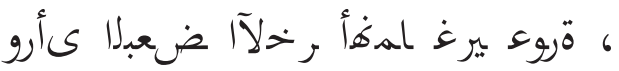

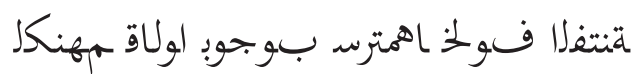
رصانخ تالتقعناف.نمزلا حلسفل ارَّظز

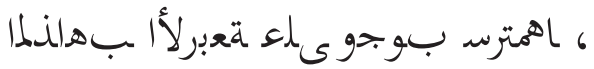

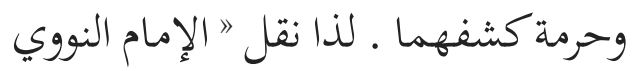

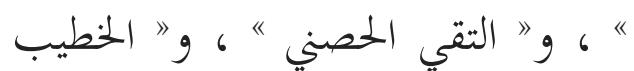

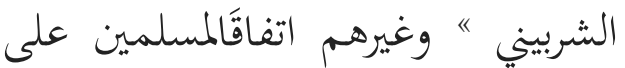
منع النساء من الخروج سافرات الوجوه

2- دَلَّت النصوص التي سقناها عن المن المذاهب الأربعة على وجوب ستر المحرمة

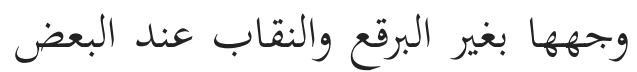
، وعلى جواز ستره بغيرهما عند مرور الرجال الأجانب بها عند البعض الآخر

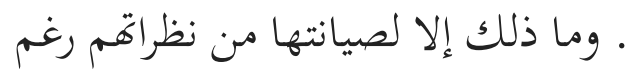

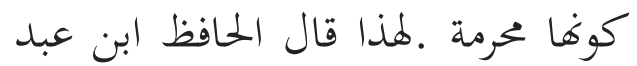

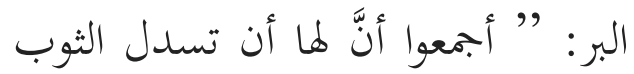
على وجهها من فوق رأسها سدلًا خفيفًا تستتر به عن نظر الرجال إليها ، ولم بيجيزوا

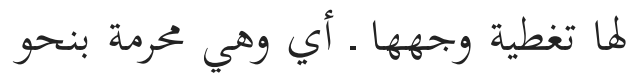

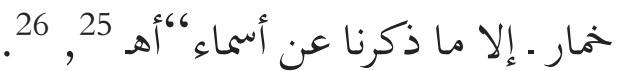

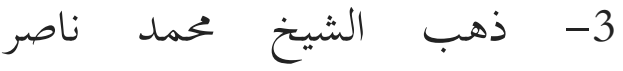

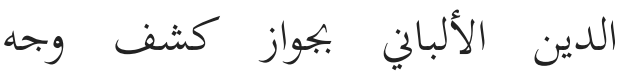
المرأة المسلمة أمام الرجال الأجحانب

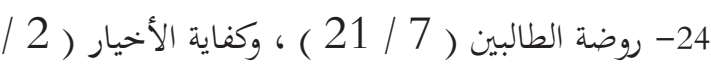

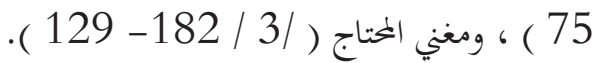
25- التمهيد لما في الموطأ من المعاني والأسانيد ج51 ) 51 ص/ 801

26- ملخصة من مقالة الشيخ أشرف بن عبد المقصود-حفظه -Bokhary63@yahoo.com 
PROFETIKA, Jurnal Studi Islam, Vol. 19, No.1 Juni 2018: 51 - 66

محتجاّ بما حصل له من الاجتهاد المستند من أقوال العلماء المتقدمين والمتأخرين - رحمه الله الجميع - - روال 4- وخالفه الألباني ( خحلافا معتبرا )

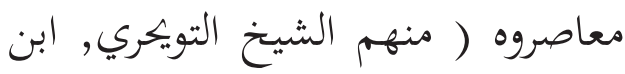
باز, وابن العثيمين ومحمد إسماعيل

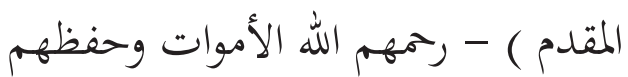
الأحياء - المعدم الم 5- القول الراجح في هذه المسألة - والله

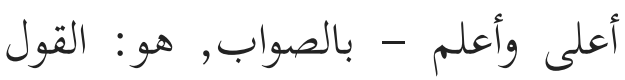
باستحباب لبس النقاب على المسلمة,

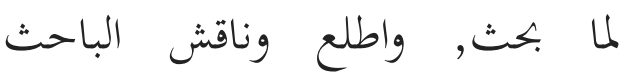
من الأساتذة الفضلاء, والأصحاب الكرماء, ووافق الباحث بما ذهب الإن إليه الشيخ الألباني دون - تعصبٍ وتقليدٍ

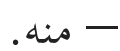
وكما أوصي الباحث بما يلي:

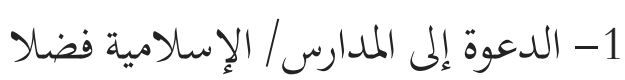

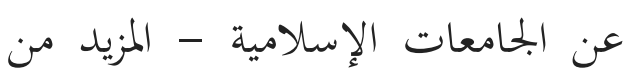
التعليم مع التطبيق العملي في الأحكام

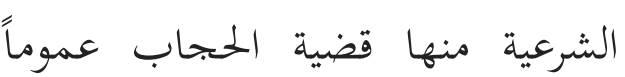
والنقاب خصوصاً.

2- ينبغي الاهتمام بمسألة الحجاب خاصة النقاب لما فيهما من المقاصد الشريعة وهي حفاظا عن النفس المسلمة من التحديات الهدامة والشبهات القاتلة الهالكة. 3- كما أوصي من تصدى 》بالفتوى《اله

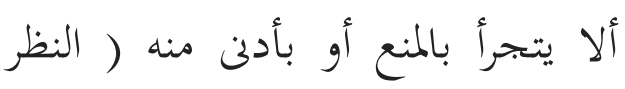

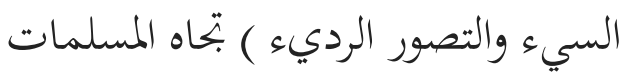

المتنقبات في المدارس والجامعات. 4- أن معرفة المسلم بحكم الحجاب|

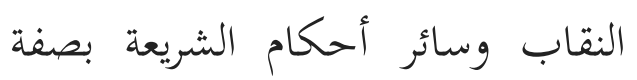
عامة, تستوجب عليه كثرة الشكر لله رب العزة والجلالة, الذي شرع المكلفين بما ينفعهم في الدنيا والآخرة, ويرفع عنهم الحرج والمشقة. 5- أن النقاب مختلف في حكمه ما ماتفة بين الواجب والمستحب, ولكل قول

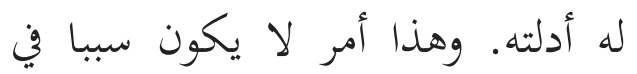

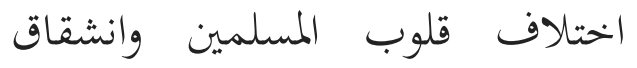
صفوفهم وتشتيت شنملهم وتضغيف وناب ماستهم وقواهم. وقد توصل هذا البحث إلى النتائج

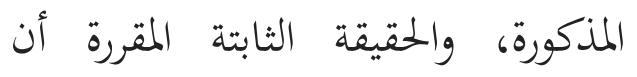

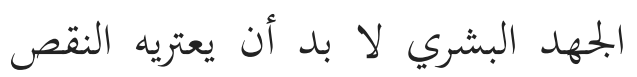

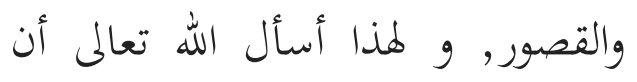
أكون قد وفقت في خدمة هذا البحث

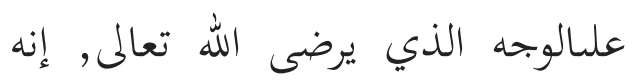

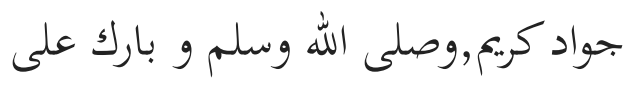

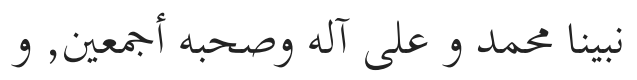
آخر دعوانا الحمد لله رب العالمين. 


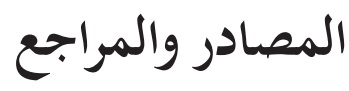

محمد بن إسماعيل أبو عبد الله البخاري الجعفي. صحيح البخاري(4750) المقق: محمد البماعيل البو البخاري الجعفي

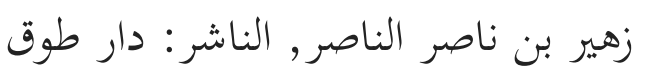
النجاة (مصورة عن السلطانية بإضافة ترقيم

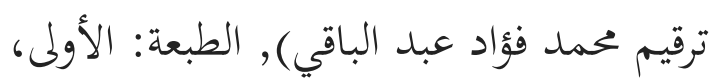
1422هـ

الإمام ابن عبد البر , الانتقاء في فضائل الأئمة الثلاثة الفقهاء " الطبعة الأولى بدار الإمام

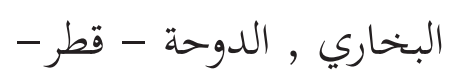

الأعلام قاموس تراجم لأشهر الرجال و النساء

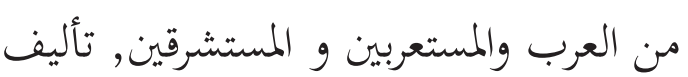
خير الدين الزركلي

الصارم المسلول على شاتم الرسول, تحقيق:

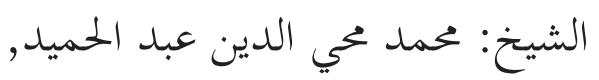

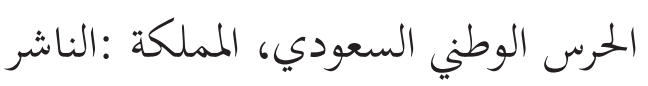

$$
\text { العربية السعودية }
$$

بحموع الفتاوى,شيخ الإسلام أحمد بن عبد

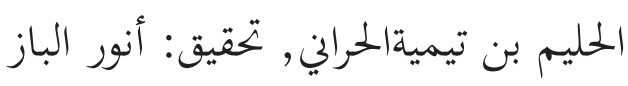
وعامر الجزار، دار الوفاء الطبعة الثالثة

$$
1426
$$

المصباح المنير في غريب الشرح الكبير,

تأليف:أحمد بن محمد بن علي المقري. وزارة المعارف العمومية بمصر، الطبعة الخامسة,

بالمطبعة الأميرية بالقاهرة 1922م المعرم المعبعة المامعة رفع الملام عن الأئمة الأعلام, تأليف: شيخ الفاهرة
أحكام النقاب عند الألباني والأئمة الأربعة (Amri Azhari)

$$
\text { الإسلام تقي الدين أبو العباس أحمد بن عبد }
$$

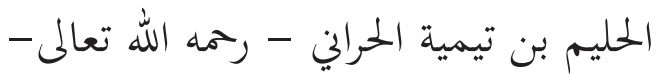

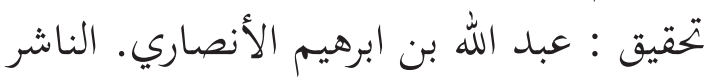
: المكتبة العصرية، بيروت، لبنان.

رفع الملام عن الأئمة الأعلام, تأليف: شيخ الإسلام تقي الدين أبو العباس أحمد بن عبد الحبد الحبل

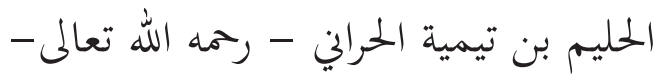

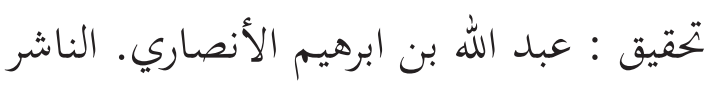
: المكتبة العصرية، بيروت، لبنان.

الدكتور إبراهيم أنيس وغيره, المعجم الوسيط ، بحمع اللغة العربية بالقاهرة الطبعة الثانية بلا سنة

الألبانى محمد ناصر الدين, جلباب المرأة المسلمة

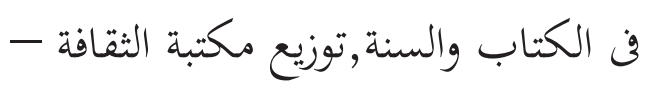

$$
\text { عدن - دار التيسير - صنعاء }
$$

معجم المحدثين والمفسرين والقراء بالمغرب الأقصى, للشيخ عبد العزيز بن عبد الله, الله

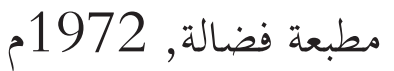
أبوالفداء إسماعيل بن عمر بن كثير القرشيالدمشقي, . تفسير القرآن العظيم, دار

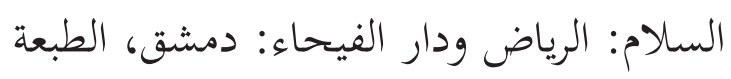
الثانية 1418هـ

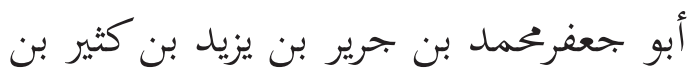

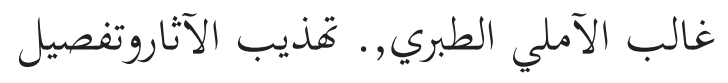
الثابت عن رسول الله من الأخبار , تحقيق:

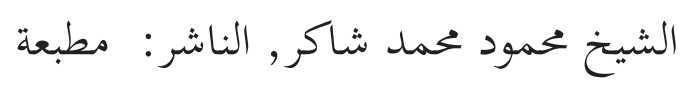
المدني - القاهرة 
PROFETIKA, Jurnal Studi Islam, Vol. 19, No.1 Juni 2018: 51 - 66

$$
\begin{aligned}
& \text { شرح الزرقاني على موطأ الامام مالك } \\
& \text { الشافعي, الإمام محمد بن إدريس, الأم, المران }
\end{aligned}
$$

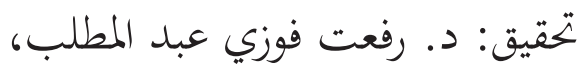

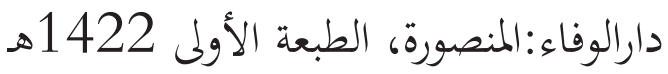

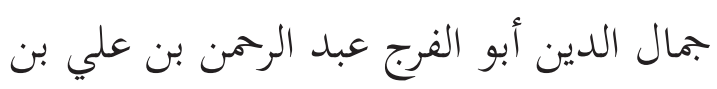

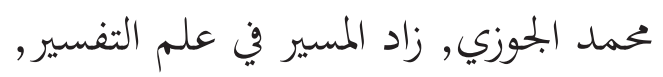

$$
\begin{aligned}
& \text { تحقيق: عبد الرزاق المهدي, الناشر: دار المسير في الثمبري } \\
& \text { الكتاب العربي - بيروتالطبعة الأولى - } \\
& \text { 1422 هـ هروئ } \\
& \text { أبوعمر يوسف بن عبد الله بن محمد بن عبد }
\end{aligned}
$$

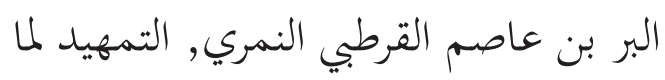

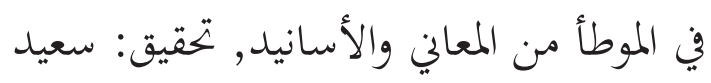

$$
\begin{aligned}
& \text { أحمد أعراب، مؤسسة القرطبة، } 141 \text { ـهـ } \\
& \text { مقالة الشيخ أشرف بن عبد المقصود-حفظه الله }
\end{aligned}
$$

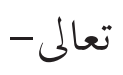

Bokhary63@yahoo.

comlibrary/0/39488/\#ixzz

$$
55 k 6 q Q 46 R
$$

http://www.alukah.net/library/0/3944

8/\#ixzz55k6qQ46R 